\title{
FEASIBILITY OF APPLICATION OF FINITE ELEMENT METHOD IN SHOE SLIP RESISTANCE TEST
}

\author{
Quting HUANG ${ }^{1}$, Mingyu $\mathrm{HU}^{1}$, Bo XU ${ }^{1}$, Jianxin $\mathrm{WU}^{2}$, Jin $\mathrm{ZHOU} \mathrm{U}^{1,2}$ \\ ${ }^{1}$ National Engineering Laboratory for Clean Technology of Leather Manufacture, Sichuan University; Chengdu 610065, P. R. \\ China
}

${ }^{2}$ Science Lab, Zhejiang Red Dragonfly Footwear Co., LTD., Zhejiang Province, Wenzhou 325100, P. R. China

Received: 30.01 .2018

Accepted: 17.05 .2018

https://doi.org/10.24264/Ifj.18.2.9

\section{FEASIBILITY OF APPLICATION OF FINITE ELEMENT METHOD IN SHOE SLIP RESISTANCE TEST}

ABSTRACT. Finite element analysis (FEA) has been widely used in engineering and construction in simulating forces and interactions and its application in footwear have become quite ripe by being researched for over 30 years. The aim of this study was to investigate the slip resistance of the outsole to learn (1) the feasibility of FEA in the test of outsole slip resistance (2) frictional interactions between outsole and contact surface by experiment test and finite element analysis. A static friction tester was used for static slip resistance test and a SATRA STM 603 slip resistance tester was used for dynamic slip resistance test. Outcome showed that value of SCoF was a little bit higher than that of DCoF both in ET and FEA, and value of coefficients obtained in ET was higher. With the increase of COF value, the displacement of outsole decreased while stress of the outsole increased. In conclusion, FEA application is feasible in footwear resistance testing. Stability of the outsole with superior slip resistance is good in both longitudinal and transverse direction. During walking, it has a strong resistance to the slipping tendency to prevent tumble and sprain.

KEY WORDS: Finite element model, Coefficient of friction, Slip resistance, Outsole

FEZABILITATEA APLICĂRII METODEI ELEMENTELOR FINITE LA TESTAREA REZISTENTEI LA ALUNECARE A ÎNCĂLTĂMINTEI

REZUMAT. Analiza elementelor finite (FEA) a fost utilizată pe scară largă în domeniul ingineriei şi construcţiilor pentru simularea forţelor şi a interacţiunilor, iar aplicarea acesteia în domeniul încălțămintei are o istorie îndelungată, fiind cercetată de peste 30 de ani. Scopul acestui studiu a fost de a investiga rezistenţa la alunecare a tălpii exterioare pentru a determina: (1) fezabilitatea FEA la încercarea de rezistenţă la alunecare a tălpii exterioare; (2) interacțiunile de frecare dintre talpa exterioară şi suprafaţa de contact prin testarea experimentală şi analiza elementelor finite. S-a folosit un aparat de testare a fricţiunii statice pentru testul de rezistenţă la alunecare statică şi un aparat de testare a rezistenţei la alunecare SATRA STM 603 pentru testul de rezistenţă la alunecare dinamică. Rezultatul a arătat că valoarea coeficientului de frecare în statică (SCOF) a fost puţin mai mare decât cea a coeficientului de frecare în dinamică (DCoF) atât în cazul testării experimentale, cât şi FEA, iar valoarea coeficienţilor obţinuţi în cazul testării experimentale a fost mai mare. Odată cu creşterea valorii COF, deplasarea tălpii a scăzut în timp ce presiunea asupra tălpii a crescut. În concluzie, aplicarea FEA este fezabilă în testarea rezistenţei la încălţ̧ăminte. Stabilitatea tălpii cu rezistenţă superioară la alunecare este bună atât în direcţia longitudinală, cât şi în cea transversală. În timpul mersului, talpa are o rezistenţă puternică la tendinţa de alunecare pentru a preveni căderea şi entorsa.

CUVINTE CHEIE: model cu elemente finite, coeficient de frecare, rezistenţă la alunecare, talpă exterioară

LA FAISABILITÉ D’APPLICATION DE LA MÉTHODE DES ÉLÉMENTS FINIS DANS L'ESSAI DE RÉSISTANCE AU GLISSEMENT DES CHAUSSURES RÉSUMÉ. L'analyse par éléments finis (FEA) a été largement utilisée dans l'ingénierie et la construction pour simuler les forces et les interactions et son application dans le domaine de chaussures est devenue a une longue histoire grâce aux recherches menées depuis plus de 30 ans. Le but de cette étude a été d'étudier la résistance au glissement de la semelle extérieure pour apprendre : (1) la faisabilité de FEA dans le test de résistance au glissement de la semelle extérieure, (2) les interactions de frottement entre la semelle extérieure et la surface de contact par le test expérimental et l'analyse par éléments finis. Un testeur de frottement statique a été utilisé pour l'essai de résistance au glissement statique et un testeur de résistance au glissement SATRA STM 603 a été utilisé pour le test de résistance au glissement dynamique. Les résultats ont montré que la valeur du coefficient de frottement en statique (SCoF) était un peu plus élevée que celle du coefficient de frottement en dynamique (DCOF) dans le test expérimental et FEA, et que la valeur des coefficients obtenus dans le test expérimental était plus élevée. Avec l'augmentation du COF, le mouvement du pied diminuait tandis que la pression sur les semelles augmentait. En conclusion, l'application de FEA est réalisable dans les tests de résistance des chaussures. La stabilité de la semelle à résistance au glissement élevé est bonne à la fois dans les directions longitudinale et transversale. Pendant la marche, la semelle présente une forte résistance au glissement pour éviter la chute et l'entorse.

MOTS CLÉS : modèle d’éléments finis, coefficient de frottement, résistance au glissement, semelle extérieure

\footnotetext{
* Correspondence to: Assoc. Prof. Dr. Jin ZHOU, National Engineering Laboratory for Clean Technology of Leather Manufacture, Sichuan University; Chengdu 610065, P. R. China; Fax:008613880467494, zj_scu@scu.edu.cn
} 


\section{INTRODUCTION}

As a part in direct contact with the ground, the outsole undertakes most functions of footwear, in which the slip resistance is an important one. Slip resistance of outsole refers to its ability to stop slipping, which has a great impact on safety and comfort of footwear. An outsole of superior slip resistance can effectively prevent slipping and improve stability during walking to ensure personal safety.

Studies on shoe slip resistance have been reported worldwide. Some studies [1, 2] found that slip resistance of outsole can be evaluated by the use of static coefficient of friction (SCOF) and dynamic coefficient of friction (DCoF). Tsai et al. [3] discussed the effect of the hardness of outsole on slip resistance. Valiant et al. tested the slip resistance of outsole made of different materials. Ura et al. [4] studied temperature's influence on outsole slip resistance. Besides, there have been several studies [5-8] focused on the effect of outsole pattern. Li et al. [6] investigated the effect of depth of outsole pattern on slip resistance. Yamaguchi et al. [7] and Shao-Xun et al. [8] studied the relationship of different contact surfaces and the outsole pattern.

Although previous studies have carried out a lot of explorations on the slip resistance of outsole, they were simply limited to real experiment tests (ET). Detailed descriptions such as intrinsic-mechanism of slip resistance while the outsole was in contact with the contact surface was lacking, since the complicated interaction between outsole and contact surface including stress, strain and deformation is too difficult to be obtained by ET. However, this problem can be solved with the finite element method.

Finite Element Analysis (FEA) is an effective method for computer analysis of complex solid geometry involving several materials, with different properties [9]. FEA works by building a model and setting material properties along with boundary conditions. Then, by dividing the model into finite elements and inputting the environmental factors to obtain the result. The accuracy of the above operations will have a great impact on the accuracy of the final results.

In this study, both ET and FEA were used to investigate the slip resistance of outsole to learn (1) the feasibility of FEA in the test of outsole slip resistance; (2) frictional interactions between outsole and contact surface. The result would provide effective theoretical support for footwear test and design.

\section{METHODS}

\section{Subject}

There were two parts in this study. The first part was ET. The shoe tested was a high heel shoe with a $50 \mathrm{~mm}$ heel-height. Its outsole was made of TPU, shore $A 80^{\circ}$ in hardness, $5 \mathrm{~mm}$ in thickness. The pattern of the outsole was transverse stripes (Figure 1). The test was carried out on several square bricks. Slip resistance of outsole was evaluated by SCoF and DCoF. The second part was FEA. The three-dimensional finite element model of the outer sole was established in ANSYS 15.0 (V15.0, ANSYS Inc., USA). The static and dynamic slip resistance tests were carried out separately. The equivalent CoF was calculated to confirm the feasibility of the FEA and the slip resistance was investigated.

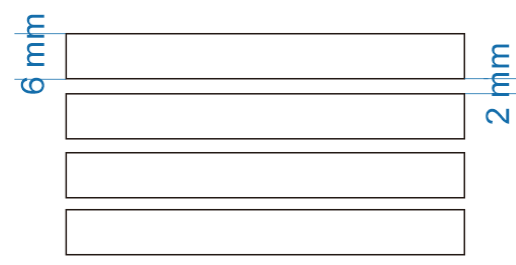

Figure 1. The pattern of the outsole test piece

\section{Procedure}

\section{Experimental Test}

The SCoF of the outsole was tested on a static friction tester. According to HG/T37802005 "Test method of static slip resistance for footwear" [10], a sample of outsole was cut out for testing. The test piece was put on a standard friction panel with a normal pressure of $27.3 \mathrm{~N}$ from horizontal direction exerted during testing. The maximum pulling force in the case of sliding was recorded. The SCoF was calculated by the formula $\mathrm{f}=\mu \mathrm{N}$ and the sample was tested 5 times for obtaining an average value.

SATRA STM 603 slip resistance tester (STM 603, SATRA, UK) (Figure 2) was used for 
the dynamic slip resistance test, according to SATRA TM144-2011 "Friction (slip resistance) of footwear and floorings" [11]. The instrument imposed a specified pressure on the test piece by a pressure device placed at the top to force contact with the test surface. The frequency and velocity of the friction test should be preset so that the relative motion of the shoe and the test surface will be carried out at constant speed. The force in the horizontal direction was measured by a horizontal sensor. The dynamic friction factor was calculated by the formula $f=\mu \mathrm{N}$ and the sample was tested 5 times for an average value.

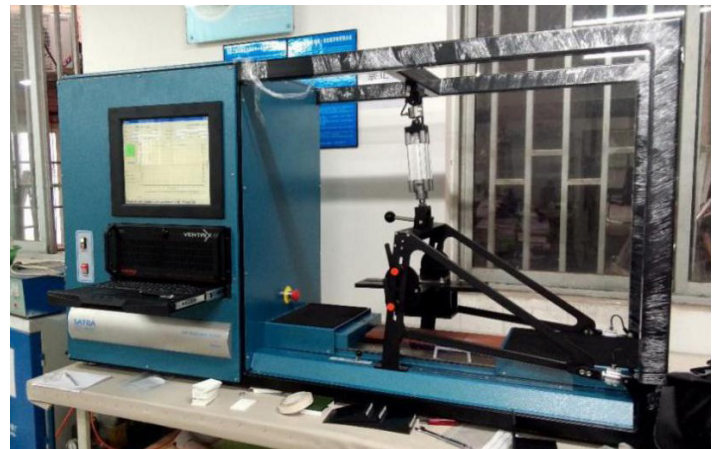

Figure 2. SATRA STM 603 slip resistance tester

\section{Finite Element Analysis}

Three-dimensional finite element model of outsole was established in ANSYS 15.0 according to a three-dimensional scanned model, for analysis of the SCoF and DCoF. The static slip resistance was tested by the test piece (Figure $3 \mathrm{~A})$ of outsole while the dynamic slip resistance test used the entire outsole for testing (Figure $3 B)$. Furthermore, the deformation while the outsole was in contact with the floor surface was studied by finite element modeling.

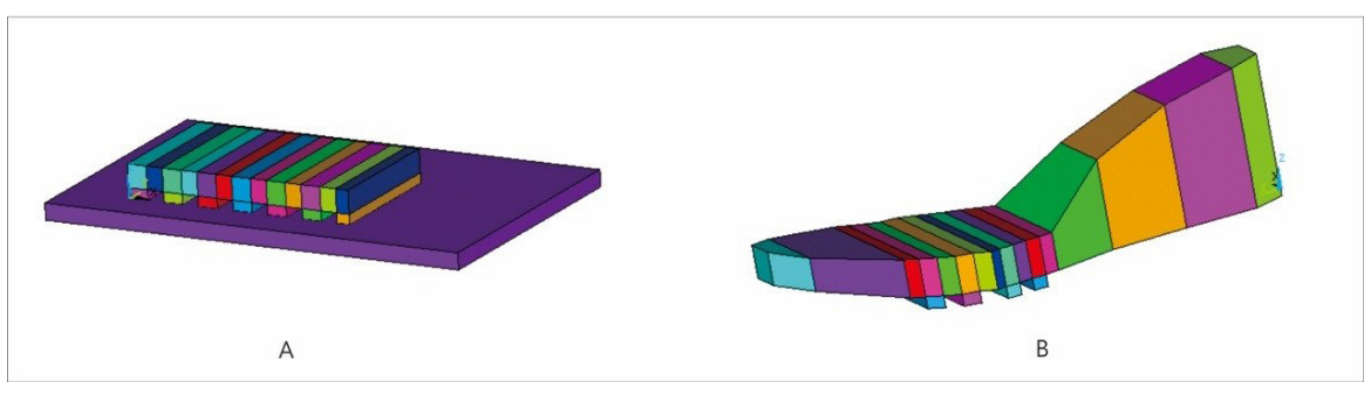

Figure 3. The 3D geometric model: $(A)$ the model of the outsole test piece and $(B)$ the model of the outsole

The Classic Mechanical APDL Product Launcher was used for analysis. ANSYS15.0 LS - DYNA modular was used on the outsole finite element model for displaying dynamics analysis and the element type was 3D Solid164.

The material of the outsole was defined as thermoplastic elastomer, the modulus of elasticity was set to $7.8 * 106 \mathrm{~Pa}$ and Poisson ratio was set to 0.47 . The rigid body was used to simulate the ground and all degrees of freedom on the ground were restricted. The meshed model is shown in Figure 4.

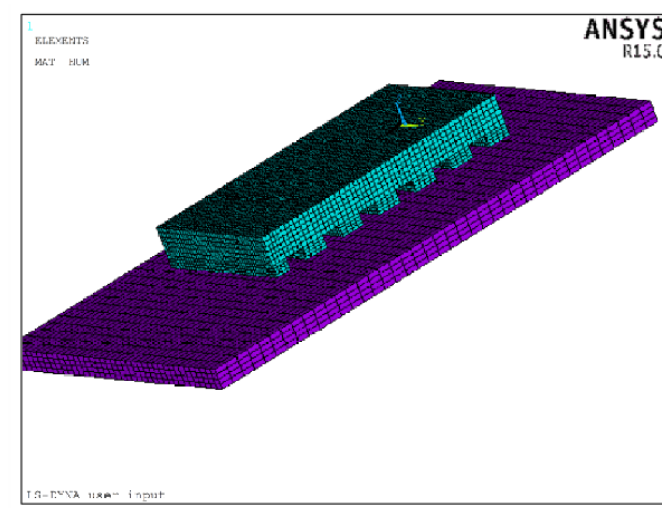

Figure 4. Meshing of the finite element model in static friction testing 
Dynamic slip resistance testing was a little bit complex as forces from both transverse and vertical direction were exerted. FEA on dynamic slip resistance is different from ET. The DCoF is also a preset value in the FEA because DCoF is only determined by the property of the material. DCoF in this paper was set to $0.4,0.5$ and 0.6. The meshed model is shown in Figure 5.

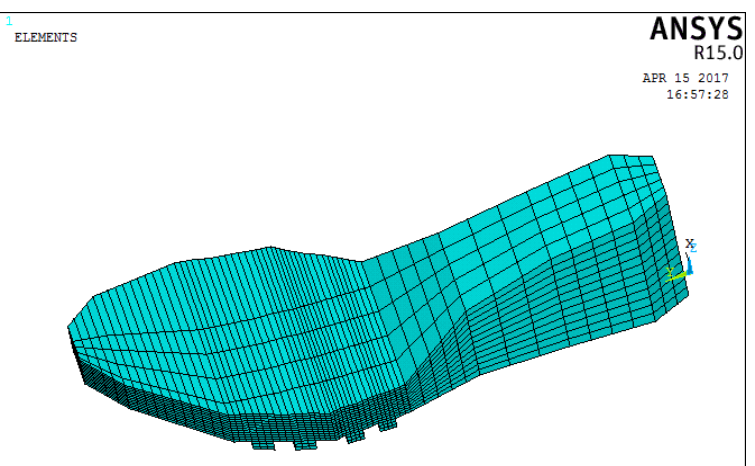

Figure 5. Meshing of the outsole model with ANSYS

Velocity boundary conditions were set to move the outsole relative to the floor. The contact pressure was controlled by the vertical displacement of the nodes on the top of the outsole [12]. This downward movement continued until an average normal force of $400 \mathrm{~N}$ was achieved. The force was set to match the experimental conditions that were used in the ET that is of the same value of magnitude of normal force during walking. The second loading step moved the nodes on the top surface of the outsole in the shear direction at the desired speed relevant to slipping.

The equivalent CoF was calculated by the ratio of average shear force to the average normal force between the two surfaces in step two. Deformation and Stress of outsoles under different COF values were recorded.

\section{RESULTS}

\section{Experiment Test}

Under dry condition, SCoF between outsole and contact surface was 0.565 and DCoF was 0.554 after taking average.

\section{Finite Element Analysis}

\section{Equivalent CoF Obtained in FEA}

The equivalent $\mathrm{SCoF}$ in finite element test was 0.602 and the equivalent DCoF was 0.589.

\section{Static Slip Resistance Test}

The static friction deformation cloud chart of the outsole test piece model is shown in Figure 6. It shows that the outsole deformed during static friction process. The force in transverse direction of the node was $0.0226 \mathrm{~N}$. The maximum stress of the node was $8 * 105 \mathrm{~Pa}$ and the minimum stress of the node was $-3.09 * 104 \mathrm{~Pa}$.

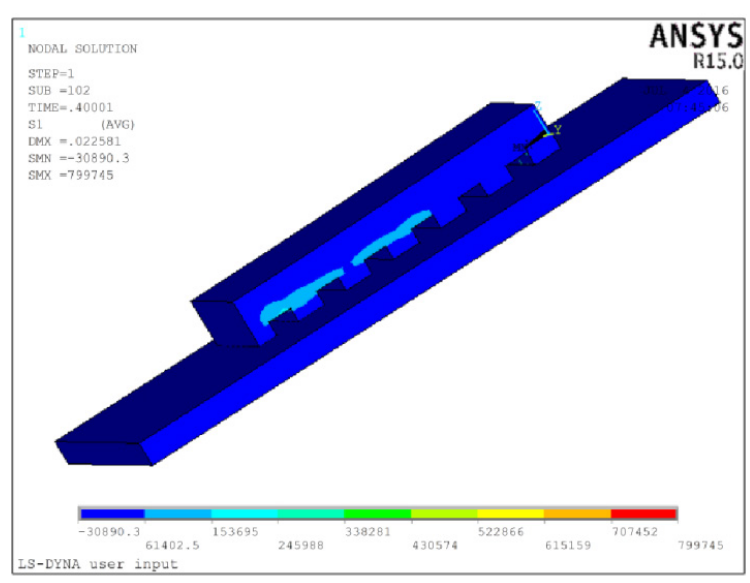

Figure 6. The finite element analysis results of outsole test piece model

\section{Dynamic Slip Resistance Test}

The result of dynamic friction test was calculated according to the preset parameters. Displacement data of outsoles under different COF values is shown in Table 1. 
Table 1: The displacement data of outsoles under different COF values

\begin{tabular}{|c|c|c|c|c|c|c|c|c|}
\hline \multirow{3}{*}{ Direction } & \multicolumn{2}{|c|}{$\begin{array}{l}\text { OF } 0.4 \\
\text { Displacement }\end{array}$} & \multicolumn{3}{|c|}{$\begin{array}{l}\text { COF } 0.5 \\
\text { Displacement }\end{array}$} & \multicolumn{3}{|c|}{$\begin{array}{l}\text { COF } 0.6 \\
\text { Displacement }\end{array}$} \\
\hline & \multicolumn{2}{|c|}{$/ \mathrm{mm}$} & Direction & \multicolumn{2}{|c|}{$/ \mathrm{mm}$} & \multirow{2}{*}{ Direction } & \multicolumn{2}{|c|}{$/ \mathrm{mm}$} \\
\hline & Max & Min & & Max & Min & & Max & Min \\
\hline$x$ & 0.3 & -0.8 & $x$ & 0.2 & -0.5 & $x$ & 0.9 & -0.8 \\
\hline $\mathrm{Y}$ & 19.2 & -1.3 & $\mathrm{Y}$ & 10.9 & -2.1 & Y & 7.3 & -2.6 \\
\hline Z & 33.5 & -40.1 & Z & 13.5 & -34.3 & Z & 0.4 & -25.6 \\
\hline $\begin{array}{c}\text { Maximum } \\
\text { displacement }\end{array}$ & & & $\begin{array}{c}\text { Maximum } \\
\text { displacement }\end{array}$ & & & $\begin{array}{c}\text { Maximum } \\
\text { displacement }\end{array}$ & & \\
\hline
\end{tabular}

It can be seen from Table 1 that the bigger the COF is, the smaller the maximum displacement of the outsole will be. The change of displacement in $Y$ (anterior-posterior) direction was consistent with the change of maximum displacement. There was no apparent regularity found in the lateral displacement in $\mathrm{X}$ (medio-lateral) direction with the change of COF value. The displacement in $\mathrm{Z}$ (vertical) direction decreased with the increase of COF value. The displacement images of testing outsoles under different COF values are shown in Figure 7.

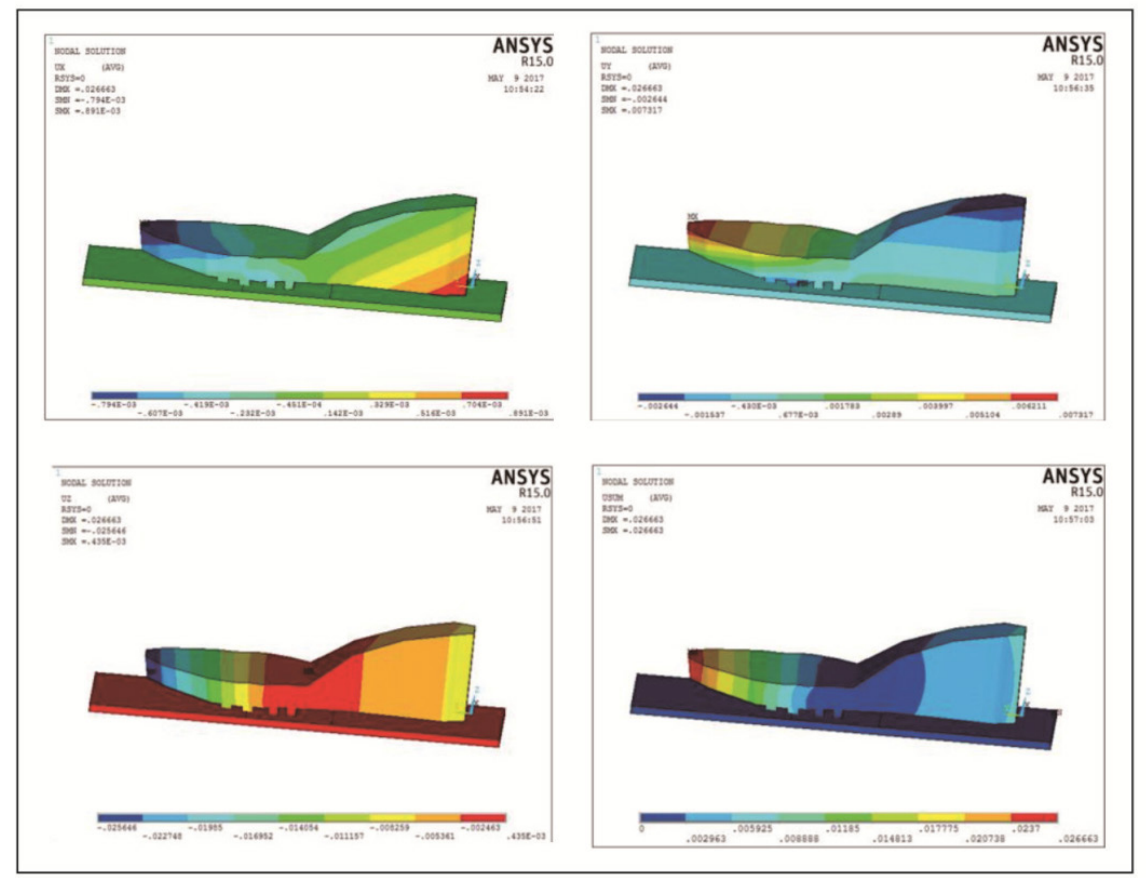

A 


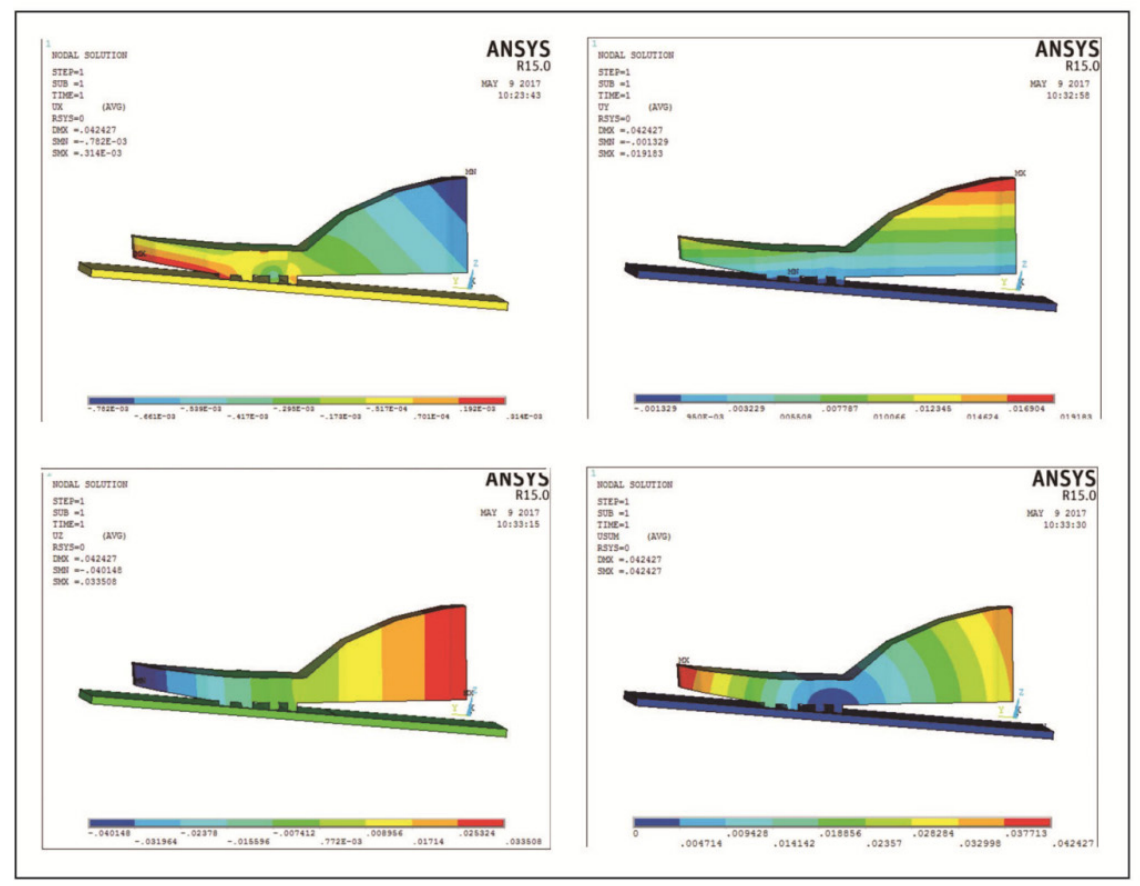

B

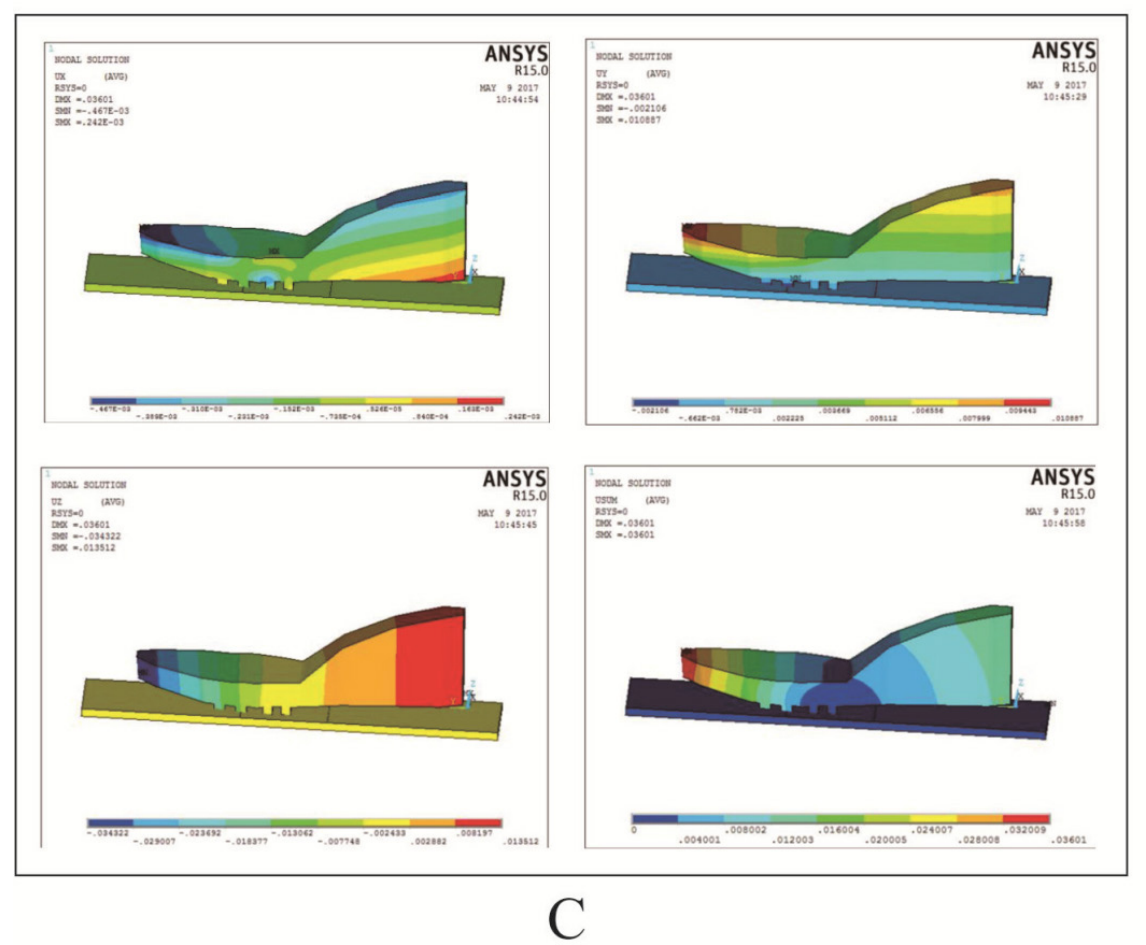

Figure 7. The displacement images of outsoles under the COF value of 0.4 (A), 0.5 (B), 0.6 (C) 
The stress data of outsoles under different COF values is shown in Table 2.

Table 2: The stress data of outsoles under different COF values

\begin{tabular}{ccccccc}
\hline \multirow{2}{*}{ Direction } & \multicolumn{2}{c}{ Stress/MPa } & Direction & \multicolumn{2}{c}{ Shear stress $/ \mathrm{MPa}$} \\
& & Max & Min & & Max & Min \\
\hline \multirow{2}{*}{ COF 0.6 } & $\mathrm{X}$ & 1.37 & -0.95 & $\mathrm{XY}$ & 1.03 & -0.72 \\
& $\mathrm{Y}$ & 1 & -1.44 & $\mathrm{YZ}$ & 2.22 & -1.38 \\
& $\mathrm{Z}$ & 3.42 & -6.24 & $\mathrm{XZ}$ & 0.98 & -1.16 \\
COF 0.5 & $\mathrm{X}$ & 1.03 & -0.75 & $\mathrm{XY}$ & 0.74 & -0.65 \\
& $\mathrm{Y}$ & 0.85 & -1.34 & $\mathrm{YZ}$ & 1.38 & -1.13 \\
& $\mathrm{Z}$ & 2.1 & -5.07 & $\mathrm{XZ}$ & 0.85 & -0.93 \\
COF 0.4 & $\mathrm{X}$ & 0.63 & -0.52 & $\mathrm{XY}$ & 0.41 & -0.52 \\
& $\mathrm{Y}$ & 0.79 & -1.48 & $\mathrm{YZ}$ & 0.79 & -1.12 \\
& $\mathrm{Z}$ & 0.7 & -3.5 & $\mathrm{XZ}$ & 0.71 & -0.64 \\
\hline
\end{tabular}

Table 2 shows that the maximum and minimum stress of the outsole increased with the increase of COF. The magnitude of the preset dynamic friction factor has influence on the force in $\mathrm{X}, \mathrm{Y}$ and $\mathrm{Z}$ directions. Stress images of testing outsoles under different COF values are shown in Figure 8.

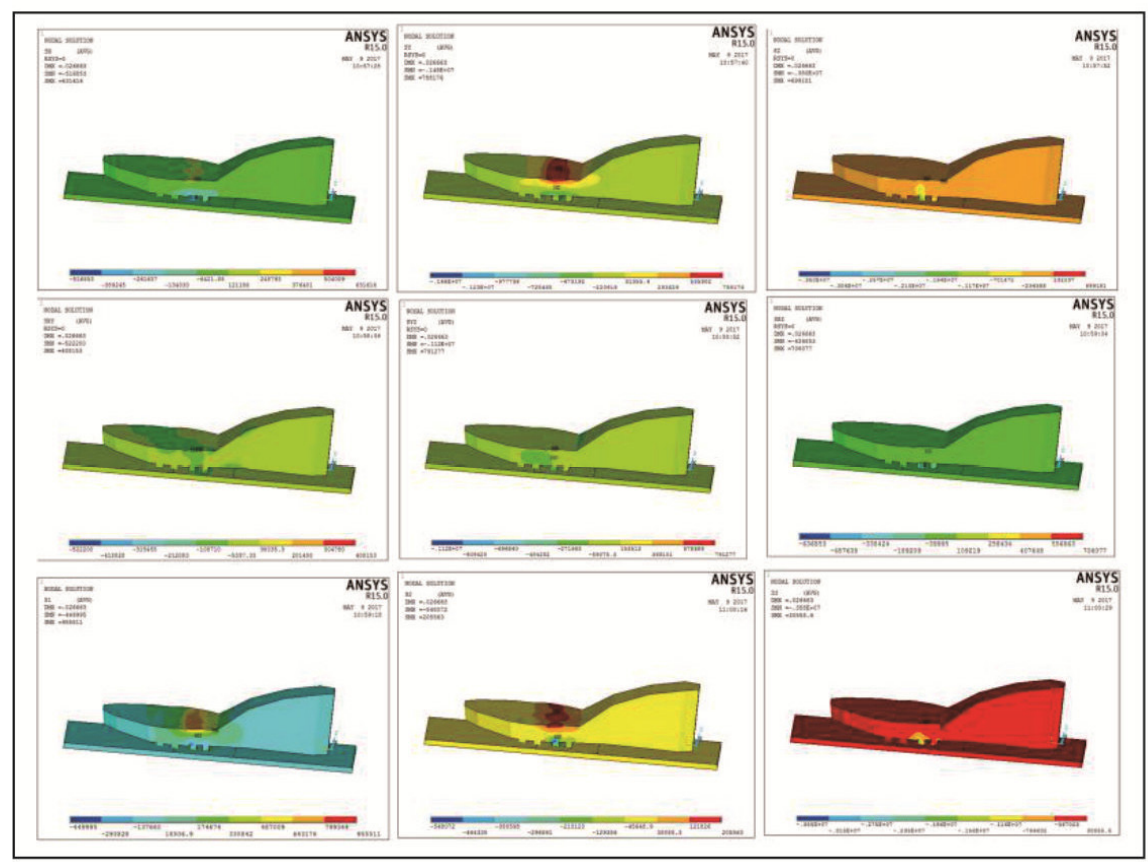

A 


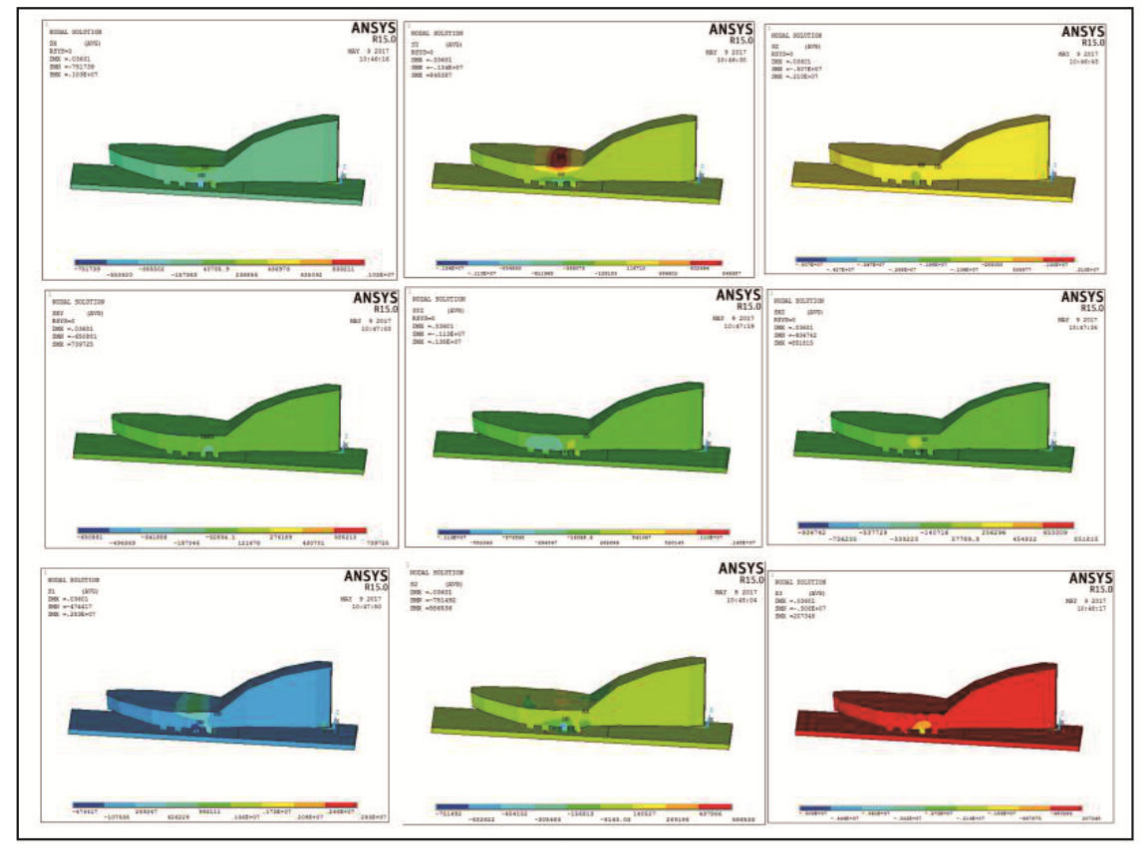

B

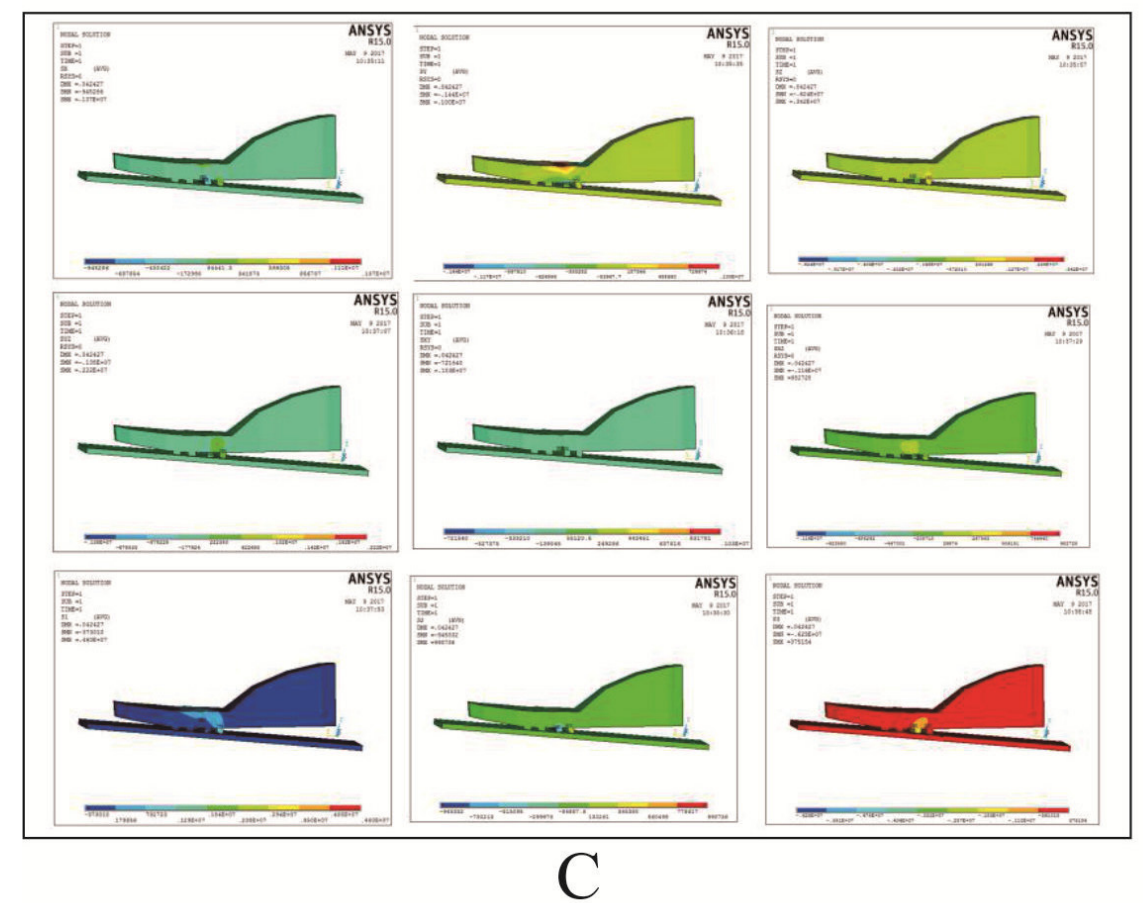

Figure 8. The stress images of testing outsoles under the COF value of $0.4(A), 0.5$ (B), 0.6 (C)

\section{DISCUSSION}

In this study, the CoF of the TPU outsole of a female high-heeled shoe was tested by ET and FEA. The two results were so closed, that finite element model can be considered a reliable alternative to the outsole slipping test. Additionally, we further investigated the deformation and stress of the outsole in the process of static friction and dynamic friction through the analysis process. The relationship between the deformation and stress of the outsole and COF was obtained and the effect of COF on slip resistance was explained. 
Although finite element model was entirely established with reference to the entity one and the parameters of the FEA were also set completely according to the actual experimental conditions. There were still some deviations between the results of FEA and ET. These might be due to the influence of contamination in the contact surface and changing environmental temperature. Those factors would affect the final value of COF. In addition, finite element model was simplified for the convenience of calculation, and the pressure exerted on the foot from human body was simulated by the direct force method. Those practices might lead to errors.

The results showed that both in the ET and FEA the static friction factor was slightly larger than the dynamic friction factor and ranges from 0.55-0.60. It was similar to the results of previous studies [13]. The difference in the results may be caused by the hardness of outsole, the spacing and width of the outsole pattern and the experimental environment.

The study of Grönqvist et al. [2] indicated that the antiskid property of the outsole can be evaluated with the friction coefficient between the sole and the contact surface. The bigger the friction factor is, the better the slip resistance will be. This was consistent with the results of finite element analysis in current study. Table 1 showed that the displacement in both $\mathrm{Y}$ and $\mathrm{Z}$ directions decreases with the increase of COF which reveals that the transverse and vertical stability of the outsole with larger COF is much better to prevent tumble and sprain.

Table 2 shows that the stress of each node in the outsole increased with the increase of COF. This was in consistence with Coulomb friction law and the result of previous researches. Xiao et al. [14] studied antiskid property of airport pavement. They regarded the size of the stress as an indicator of the antiskid property. The larger the stress is, the better the anti-skid property will be. This is the same with the results in Table 2 . We suspect that the outsole with lager COF has a strong resistance to the tendency of slipping due to a larger deformation caused by a larger stress.

Moreover, FEA shows that the stability of the outsole with superior slip resistance is stable both in the longitudinal and transverse directions. During walking, it has a strong resistance to the slipping tendency to prevent tumble and sprain. In future research, more diversified finite element analysis should be applied on the antiskid property of the outsole with different patterns and hardness. In order to improve the reliability of finite element analysis, the model should be more in line with the entity and the simulate conditions should be constantly adjusted to match the real condition. Meanwhile, the experimental test should be used as a proof of the finite element method.

\section{CONCLUSION}

Overall, although small deviation exists, FEA must be the future development trend in the shoe testing field. With the advantages of low cost, quick analysis and wide applicability, FEA will be used in more fields in the future [1].

\section{Acknowledgement}

The study was supported by National Natural Science Foundation of China (31700813) and China Postdoctoral Science Foundation (2015M571896).

\section{REFERENCES}

1. Tisserand, M., Progress in the prevention of falls caused by slipping, Ergonomics, 1985, 28, 7, 1027-1042, https://doi. org/10.1080/00140138508963225.

2. Grönqvist, R., Abeysekera, J., Gard, G., Hsiang, S.M., Leamon, T.B., Newman, D.J. et al., Human-centred approaches in slipperiness measurement, Ergonomics, 2001, 44, 13, 1167-1199, https://doi. org/10.1080/00140130110085556.

3. Tsai, Y.J., Powers, C.M., The influence of footwear sole hardness on slip initiation in young adults, J Forensic Sci, 2008, 53, 4, 884-885, https://doi.org/10.1111/j.15564029.2008.00739.x.

4. Valiant, G.A., The relationship between normal pressure and the friction developed by shoe outsole material on a court surface, $J$ Biomech, 1987, 20, 9, 892-892, https://doi.or $\mathrm{g} / 10.1080 / 14763141.2015 .1084031$. 
5. Ura, D., Conway, J., Booth, J., Carré, M.J., Tennis shoe outsole temperature changes during hard court sliding and their effects on friction behaviour, Procedia Eng, 2015, 112, 290-295, https://doi.org/10.1016/j. proeng.2015.07.254.

6. Li, K.W., Wu, H.H., Lin, Y.C., The effect of shoe sole tread groove depth on the friction coefficient with different tread groove widths, floors and contaminants, Appl Ergon, 2006, 37, 6, 743-748, https://doi.org/10.1016/j. apergo.2005.11.007.

7. Yamaguchi, T., Hsu, J., Li, Y., Maki, B.E., Efficacy of a rubber outsole with a hybrid surface pattern for preventing slips on icy surfaces, Appl Ergon, 2015, 51, 9-17, https://doi. org/10.1016/j.apergo.2015.04.001.

8. Shao-Xun, D.U., Jie, W.U., Study on the function relationship of the ground condition and the outsole pattern of sports shoes, Journal of Shaanxi University of Science \& Technology, 2004.

9. Williamson, M.P., Finite-element analysis, Computer-Aided Engineering Journal, 1985, 2, 2, 66-69, https://doi.org/10.1049/ cae:19850013.
10. HG/T3780-2005, "Test method of static slip resistance for footwear"

11. SATRA TM144-2011, lip resistance) of footwear and floorings"

12. Moghaddam, S.R.M., Redfern, M.S., Beschorner, K.E., A microscopic finite element model of shoe-floor hysteresis and adhesion friction, Tribol Lett, 2015, 59, 3, 42.

13. Luo, X., Gong, T., Yang, M., The relationship between outsole pattern and slip resistance, China Leather, 2004, 8, 154-155.

14. Xiao, Y., Ven, M.F.C.V.D., Molenaar, A.A.A., $\mathrm{Wu}$, S.P., Stress and strain analysis in tarcontaining antiskid runways using finite element models, Constr Build Mater, 2012, $27,1,24-31$.

(C) 2018 by the author(s). Published by INCDTPICPI, Bucharest, RO. This is an open access article distributed under the terms and conditions of the Creative Commons Attribution license (http:// creativecommons.org/licenses/by/4.0/). 